\title{
FEATURES OF STRUCTURE FORMATION AND CHANGES IN THE MECHANICAL PROPERTIES OF CAST Al-Mg-Si-Mn ALLOY WITH THE ADDITION OF (Ti $+\mathrm{Zr})$
}

\author{
Oleksandr Trudonoshyn ${ }^{a, b}$, MAXIM PUChNin $^{b, *}$, \\ KOSTIANTYN MYKHALENKOV ${ }^{a}$ \\ a National Technical University of Ukraine "KPI", Polytechnichna str., 35, Build. 9, 03056, Kiev, Ukraine \\ ${ }^{b}$ Czech Technical University in Prague, FME, Karlovo náměstí 13, 12135, Prague 2, Czech Republic \\ * corresponding author: maxim.puchnin@fs.cvut.cz
}

\begin{abstract}
The as-cast and heat-treated structure of permanent mould castings of $\mathrm{AlMg}_{5} \mathrm{Si}_{2} \mathrm{Mn}$ alloys with different contents of $\mathrm{Ti}$ has been investigated by differential scanning calorimetry, hardness and microhardness measurements, tensile tests and fractography analyses, scanning electron microscopy, transmission electron microscopy, and energy dispersive X-ray analysis. We have established that $\alpha$-Al dendrites can be nucleated on an $\mathrm{Al}-\mathrm{Ti}$ substrate, and also that primary $\mathrm{Mg}_{2} \mathrm{Si}$ crystals can be nucleated on oxides, including oxides of $\mathrm{Al}$ and $\mathrm{Ti}$ compounds. The dependence of the change in mechanical properties on ageing time, and on the amount of Ti in the alloys, is shown.
\end{abstract}

KEYWORDS: Al-Mg-Si-Mn alloys; Ti addition; microstructure; mechanical properties; multi-step nucleation.

\section{INTRODUCTION}

In recent years, the key adjectives in the design of new materials have been light-weight, low-cost and ecological. Age-hardening materials have attracted attention due to their improved properties (low density, excellent castability, good wear resistance and considerable mechanical properties).

There are three mainstreams of scientific and engineering evolution in the area of aluminium alloys, in particular casting:

- designing new casting processes and improving wellestablished processes. Recent decades have seen the birth of thixo- and rheo-casting processes, which deal with semi-solid state alloys. As has been pointed out in [1, 2], there is a call for new alloys suitable for these processes;

- improved degassing and refining techniques for aluminium alloys;

- developing new alloys. This line of investigation is especially important for casting alloys, because $\mathrm{Al}$ is one of the few metals that can be cast by all of the processes used in metal casting.

While the first and second evolution processes mentioned above are of vital importance for improving casting properties and casting quality, the third process - developing new alloys - is in great demand for elaborating new cost-effective casting processes and for designing innovative components for the next generation of vehicles: trains, ships and airplanes.

One of the most significant achievements in the development of new alloys has been the creation of a series of casting alloys containing a radically new combination of elements. Instead of using the classi- cal composition Al-7\% Si-0.3\% Mg (A356), the phase equilibrium in the new alloys is enriched by magnesium in the Al-Mg-Si system [5].

The popularity and the successful implementation into foundry practice of Al-Mg-Si-Mn alloys is based on its advantages in comparison with $\mathrm{Al}-\mathrm{Si}-\mathrm{Mg}$ alloys, such as:

- these alloys have one of the highest eutectic melting points $\left(597^{\circ} \mathrm{C}\right)$ among all commercial Al casting alloys; eutectic alloys are the most suitable alloys for casting.

- the low Si concentration in a solid solution (about $0.2 \mathrm{at} \%$ ) allows additional alloying (saturation) of the Al matrix by a wide range of elements, such as $\mathrm{Zn}, \mathrm{Cu}, \mathrm{Sc}, \mathrm{Zr}, \mathrm{Cr}$, Ti, Li, or combinations of these alloys. They cannot be added to conventional $\mathrm{Al}-\mathrm{Si}-\mathrm{Mg}$ casting alloys due to the formation of silicides.

To satisfy increasing demands for lightweight structures, several variations of the $\mathrm{AlMg}_{5} \mathrm{Si}_{2} \mathrm{Mn}$ alloy have been developed. Data on the possibility of improving the mechanical properties of $\mathrm{AlMg}_{5} \mathrm{Si}_{2} \mathrm{Mn}$ by alloying with $\mathrm{Cu}, \mathrm{Zn}, \mathrm{Cr}$, Ti, Zr, Sc+Zr, Li, and heat treatment is rather limited, and is controversial [3, 6, 12 .

It is known that Al-Mg-Si belongs to the group of age-hardenable alloys, and can be heat treated to achieve a required combination of properties. The plasticity and the hardness of these alloys may be controlled by the formation of nano-dispersed particles of a second phase within the matrix. The hardening effects result from dislocation interaction, with the precipitates acting as obstacles to the dislocation motion [7, 8]. However, the optimal solution treatment 
VOL. 55 NO. 4/2015 Formation and Properties of Cast Al-Mg-Si-Mn Alloy with the Addition of (Ti $+\mathrm{Zr})$

\begin{tabular}{lcccccccc}
\hline Alloy & \multicolumn{8}{c}{ Element content, wt.\% (Al-bal.) } \\
\cline { 2 - 8 } & $\mathrm{Mg}$ & $\mathrm{Si}$ & $\mathrm{Mn}$ & $\mathrm{Ti}$ & $\mathrm{Zr}$ & $\mathrm{Fe}$ & $\mathrm{Cu}$ & $\mathrm{Zn}$ \\
\hline \multicolumn{8}{c}{ Studied alloys } \\
\hline $\mathrm{T}$ & 4.70 & 1.89 & 0.52 & 0.11 & 0.06 & 0.02 & 0.003 & 0.001 \\
$\mathrm{TP}$ & 4.67 & 1.89 & 0.51 & 0.26 & 0.08 & 0.02 & 0.003 & 0.001 \\
\hline \multicolumn{8}{c}{ Commercial alloys } \\
\hline A356 & 0.32 & 6.97 & 0.02 & - & - & 0.06 & - & - \\
M59 & 5.50 & 2.00 & 0.60 & 0.20 & 0.05 & 0.20 & 0.05 & 0.07 \\
\hline
\end{tabular}

TABLE 1. Nominal composition of alloys.

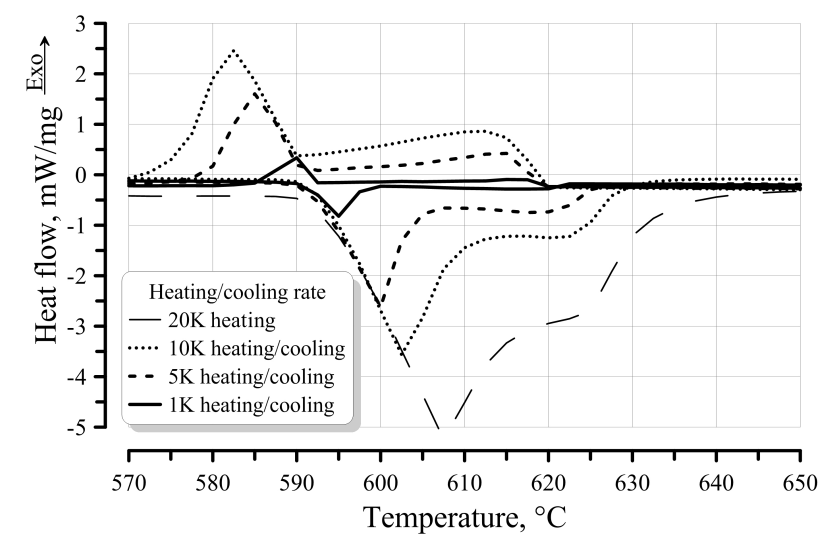

Figure 1. DSC curves of the $T$ alloy with different heating and cooling rates.

temperature and time, and also the temperature and time for artificial ageing have not yet been established.

As in the case of heat treatment, the effect of alloying $\mathrm{AlMg}_{5} \mathrm{Si}_{2} \mathrm{Mn}$ with $\mathrm{Ti}+\mathrm{Zr}$ on the structure formation and properties have not yet been dealt with satisfactorily.

\section{MATERIAL AND METHODS}

All alloys were prepared in an electric resistance furnace, using graphite crucibles. $\mathrm{AlMg}_{50}, \mathrm{AlSi}_{25}$, $\mathrm{AlMn}_{26}$ and high purity aluminum $\left(\mathrm{Al}_{99.997}\right)$ were used as master alloys. The melt with a temperature of $720 \pm 5^{\circ} \mathrm{C}$ had been degassed under an argon atmosphere for 10 minutes.

The chemical composition of the received samples was measured using a CCD-based optical emission spectrometer (OES) for Q4 TASMAN metal analysis. The chemical compositions of the evaluated alloys are presented in Tab. $1 . \mathrm{Al}_{5} \mathrm{Mg}_{2} \mathrm{Si}_{0.6} \mathrm{Mn}$ alloy was chosen as the base (denoted M59).

The heat treatment was performed in an electric resistance furnace. The first type of heat treatment was solution treatment at $570^{\circ} \mathrm{C}$, with quenching into water. The second type of heat treatment was T6, which combines solution treatment and artificial ageing at $175^{\circ} \mathrm{C}$ for different time.

Differential scanning calorimetry (DSC) measurements were performed using a NETZSCH DSC 404

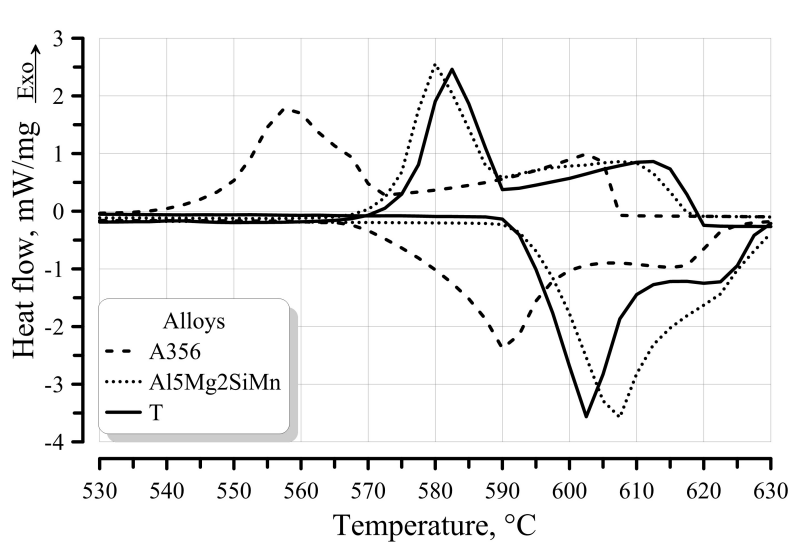

Figure 2. DSC curves of aluminum alloys (heating/cooling rate $10 \mathrm{~K} / \mathrm{min}$ ).

instrument. During the DSC measurements, the samples were protected under an argon atmosphere with a flow rate of $75 \mathrm{ml} / \mathrm{min}$. Measurements were taken in the temperature range from 20 to $700^{\circ} \mathrm{C}$ at a heating rate of $10 \mathrm{~K} / \mathrm{min}$.

Samples for microstructure observations in a scanning electron microscope (SEM) were prepared using conventional metallographic techniques. The composition of the phases was measured by EDX analysis using SEM.

Hardness was measured by a Brinell hardness testing machine $(\mathrm{HB})$ with a ball diameter of $2.5 \mathrm{~mm}$, a load of $62.5 \mathrm{~kg}$, and the loading time was $10 \mathrm{sec}-$ onds. Microhardness tests were carried out on polished non-etched specimens on an HV0.05 Duramin-2 microhardness tester, with standard indentation time.

Tensile tests were carried out on normalised specimens, using an INSTRON 5582 testing machine, according to the EN ISO 6892-1 standard.

\section{Results And Discussion}

Differential scanning calorimetry. Figures 1 and 2 show the curves of the changes in the heat flow depending on the temperature for representative alloys (with a different cooling/heating rate) and for commercial alloys. When the temperature reaches close to $590{ }^{\circ} \mathrm{C}$ on the heating curve, a negative thermal effect occurs, which corresponds to an endothermic 


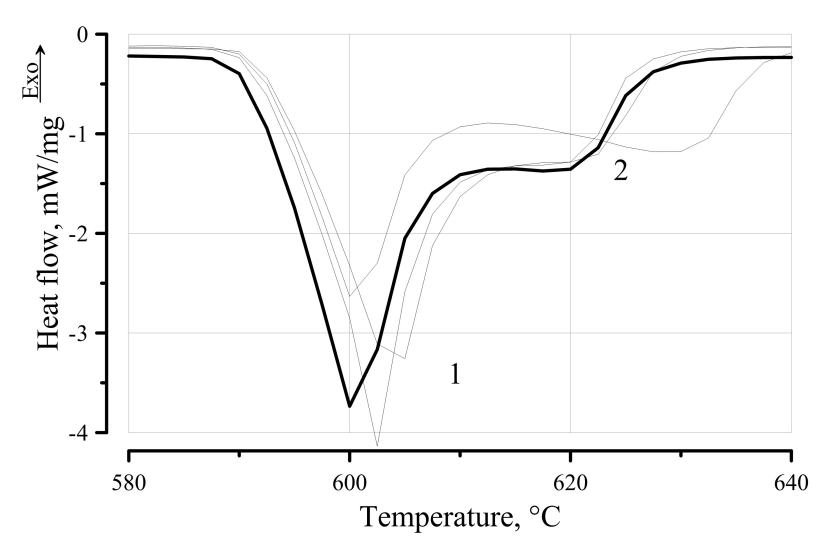

Figure 3. DSC curves of the T-alloy.

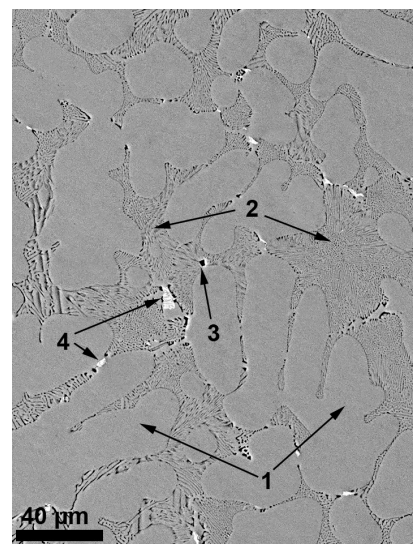

(a)

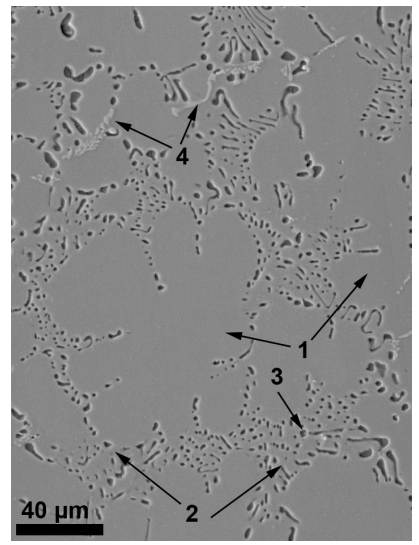

(b)

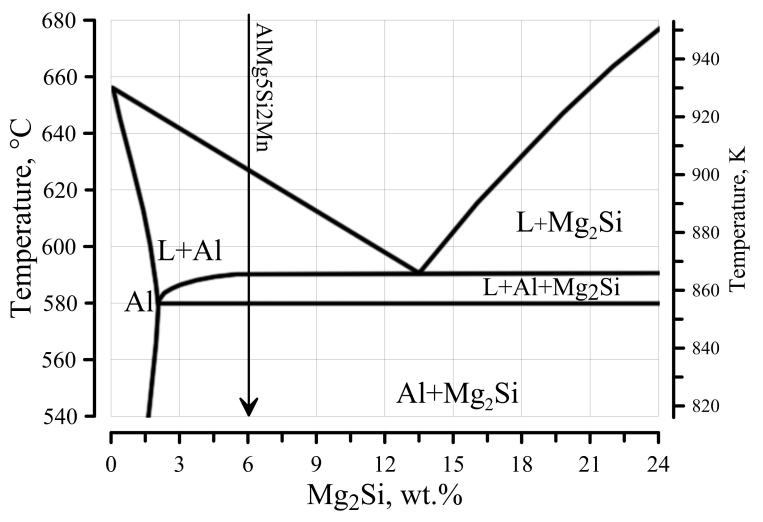

Figure 4. Phase diagram of $\mathrm{Al}-\mathrm{Mg}_{2} \mathrm{Si}$ system.

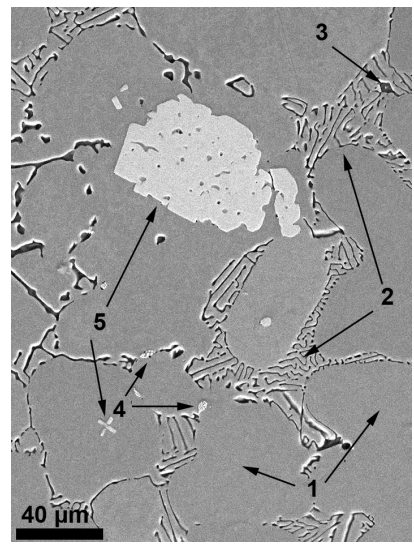

(c)

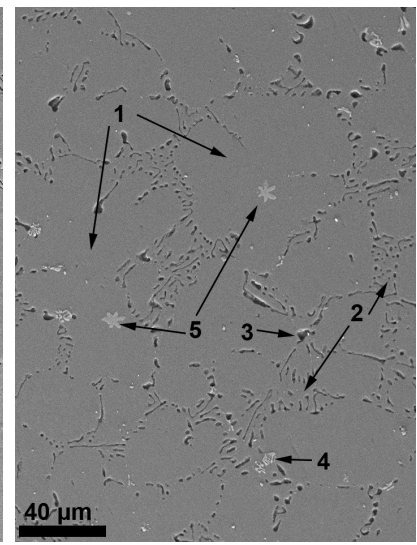

(d)

Figure 5. Microstructure of investigated alloys: (a) T-series, as-cast state, (b) T-series, solution treated, (c) TP-series, as-cast state, (d) TP-series, solution treated.

reaction. The observed effect is characterized by the following temperatures (Fig. 2):

- $\mathrm{T}_{\text {onset }}$ - melting temperature of the eutectic;

- $\mathrm{T}_{\text {peak }, 1}$ - temperature of peak 1 ;

- $\mathrm{T}_{\text {outset }}$ - the end of the thermal effect;

- $\mathrm{T}_{\text {peak }, 2}$ - temperature of peak 2 .

At low heating rate values $(\mathrm{K} / \mathrm{min})$, the magnitude of the peaks is very small, and it is impossible to identify all the thermal effects under both heating and cooling of the samples. Acceleration of the heating rate to $20 \mathrm{~K} / \mathrm{min}$ does not change temperature $\mathrm{T}_{\text {onset }}$, but it increases the absolute value of the peak. The temperatures of the peaks $\mathrm{T}_{\text {peak }, 1}$ and $\mathrm{T}_{\text {peak }, 2}$ are also shifted towards higher values (Fig. 1).

The relationship between the heating rate and the peak area was experimentally established in 5 . The change in the area of the peak is related to the fact that any phase transformation with increasing heating rate has less time to proceed.

With a heating rate of $10 \mathrm{~K} / \mathrm{min}$ in the DSC curve, two endothermic effects are clearly identified (see Fig. 3). The first endothermic effect corresponds to the melting of the eutectic $(\mathrm{Al})+\left(\mathrm{Mg}_{2} \mathrm{Si}\right)$ (marked 1).
This thermal effect starts at $\mathrm{T}_{\text {eut,onset }}=594 \pm 3{ }^{\circ} \mathrm{C}$, and the temperature at the maximum heat flow is $\mathrm{T}_{\text {peak }, 1}=602 \pm 3^{\circ} \mathrm{C}$. The second heat effect $($ marked 2$)$ corresponds to the melting of grain $\alpha$-Al. The maximum of the second peak is $\mathrm{T}_{\text {peak }, 1}=621 \pm 3{ }^{\circ} \mathrm{C}$. It has therefore been confirmed experimentally that the initial melting point of alloys of $\mathrm{Al}-\mathrm{Mg}-\mathrm{Si}$ is $594 \pm 3{ }^{\circ} \mathrm{C}$, which is $26^{\circ} \mathrm{C}$ higher than the melting temperature of commercial alloy A356.

In order to explain these effects, the DSC data was compared with the phase diagram of $\mathrm{Al}-\mathrm{Mg}_{2} \mathrm{Si}$ (Fig. 4 ). The DSC results for the commercial $\mathrm{Al}_{5} \mathrm{Mg}_{2} \mathrm{SiMn}$ alloy fully correspond with the results obtained for samples of $\mathrm{T}$ alloys. This demonstrates that the addition of $0.1 \mathrm{wt} \% \mathrm{Ti}+0.1 \mathrm{wt} \% \mathrm{Zr}$ has no effect on the type of melting and solidification of the Al-Mg-Si-Mn system of casting alloys.

In $\mathrm{Al}-\mathrm{Mg}$ alloys, according to [5, Ti and $\mathrm{Zr}$ are present in the composition of $\alpha$-Al, and they form $\mathrm{Al}_{3} \mathrm{Ti}$ and $\mathrm{Al}_{3} \mathrm{Zr}$ compounds. No information has been published about ternary compounds in the Al$\mathrm{Mg}-\mathrm{Ti}$ system. In the alloy with a nominal composition $\mathrm{Al}+1.0 \mathrm{wt} \% \mathrm{Mg}+0.05 \mathrm{wt} \% \mathrm{Zr}$ can peritectically form ternary compound $\mathrm{L}+\mathrm{Al}_{3} \mathrm{Zr} \rightarrow \mathrm{AlMgZr}+\mathrm{Al}$. However, no experimental confirmation of this reac- 


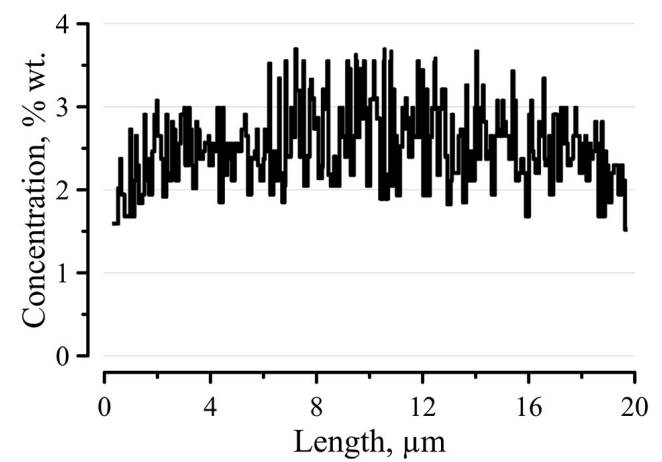

(a)

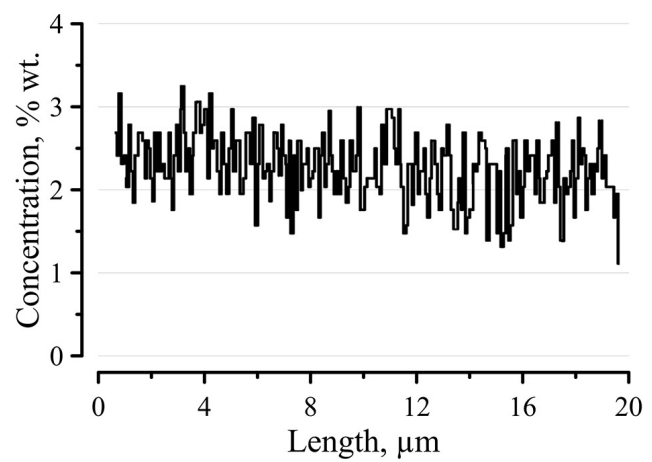

(b)

Figure 6. Distribution of Ti in $\alpha$-Al grains: (a) as-cast, (b) solution treated.

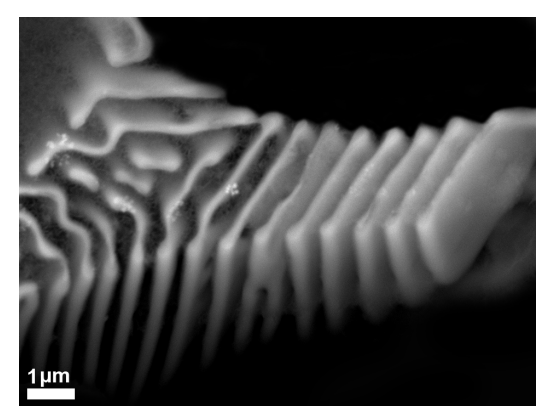

(a)

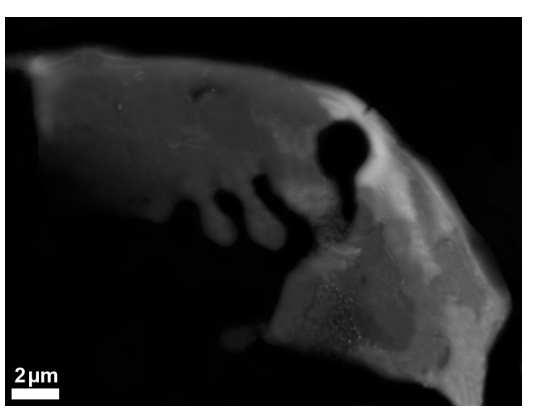

(b)

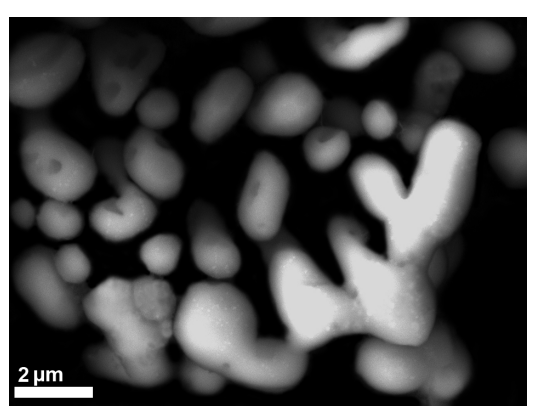

(c)

Figure 7 . Eutectic morphology during solution treatment at $570-575^{\circ} \mathrm{C}$.

tion has been provided. The absence of formation reactions of ternary compounds with $\mathrm{Ti}$ and $\mathrm{Zr}$ in Al-Mg-Si-Mn alloys was confirmed by the DSC data (no further thermal effects are detected). M59 and TP alloys include a Ti content higher than at the peritectic point of the Al-Ti binary phase diagram $(0.15 \mathrm{wt} \%)$. However, no thermal effect was observed at temperatures close to the peritectic reaction (at $665^{\circ} \mathrm{C}$ [5]), presumably due to the small amount of the $\mathrm{Al}_{3} \mathrm{Ti}$ phase.

Microstructure investigation. The structures of the base alloy and after alloying by $(\mathrm{Ti}+\mathrm{Zr})$ are shown in Fig. 5. All alloys exhibit an equiaxed grain structure, and four phase constituents can be distinguished, i.e., $\alpha$-Al solid solution (gray, denoted 1); $(\mathrm{Al})+\left(\mathrm{Mg}_{2} \mathrm{Si}\right)$ eutectic (dark, denoted 2$) ; \mathrm{Mg}_{2} \mathrm{Si}$ primary crystals (dark, denoted 3 ); $\alpha-\mathrm{Al}_{12}(\mathrm{Mn}, \mathrm{Fe}){ }_{3} \mathrm{Si}$ phase (white, denoted 4); $\mathrm{Al}_{3} \mathrm{Ti}$ intermetallic compound (white, denoted 5, only in TP alloy).

The preferential morphology of $\alpha-\mathrm{Al}$ is a dendritic structure with long primary arms for all alloys. The $(\mathrm{Al})+\left(\mathrm{Mg}_{2} \mathrm{Si}\right)$ eutectic has a lamellar morphology, where long $\mathrm{Mg}_{2} \mathrm{Si}$ plates alternate with $\alpha$-Al. Primary $\mathrm{Mg}_{2} \mathrm{Si}$ crystals have a regular polyhedral shape, and are situated in the centres of eutectic colonies. The addition of $(\mathrm{Ti}+\mathrm{Zr})$ produces a slight grain refinement effect.

During solution treatment, the phase composition remains the same as in as-cast condition, but there are changes in the morphology of the phases (Figs. 5 and 6] [10.

Element Distribution. $\alpha$-Al grain. The composition of the matrix of all alloys varies slightly. The $\alpha$-Al solid solution of all alloys contains $\mathrm{Mg}, \mathrm{Si}, \mathrm{Mn}$ and Ti. It is known that the solubility of magnesium in aluminium amounts to $1.4 \%$, and for silicon the solubility amounts to $0.4 \%$, at room temperature. The $\mathrm{Mg}$ content in a solid solution measured in SEM using $15 \mathrm{kV}$ acceleration voltage is $2.44 \mathrm{wt} \%$. The $\mathrm{Mg}$ distribution across the dendrite arm is non-homogeneous, and varies in the range from 2.3 to $2.6 \mathrm{wt} \%$.

For all alloys, the $\mathrm{Mn}$ content in an $\alpha$-Al solid solution is $0.45 \pm 0.05 \mathrm{wt} \%$. In the $\mathrm{T}$ alloy, the $\mathrm{Ti}$ and $\mathrm{Zr}$ concentration is $0.2 \mathrm{wt} \%$. Its distribution seems to be non-homogeneous and in some points (close to the center of the dendrite arms) it reaches $0.39 \mathrm{wt} \%$, which is reduced to a grain boundary up to $0.19 \mathrm{wt} \%$ (Fig. 6). The small Si content measured for SEM EDX analysis obviously originated from the surrounding $\mathrm{Mg}_{2} \mathrm{Si}$ lamellas, or from lamellas lying beneath the surface. The Si concentration in the $\alpha$-Al grains of all alloys was less than $0.4 \mathrm{wt} \%$. The average composition of the $\alpha$-Al matrix for all samples is presented here.

Eutectic. The stoichiometric composition of $\mathrm{Mg}_{2} \mathrm{Si}$ is $66.7 \mathrm{at} \% \mathrm{Mg}$ and $33.3 \mathrm{at} \% \mathrm{Si}$. The EDX spectra of the lamellas, excluding the $\mathrm{Al}$ from quantification, gave a composition of the eutectic lamella very close 


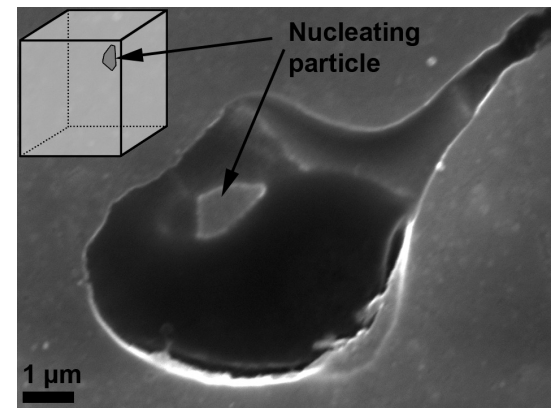

(a)

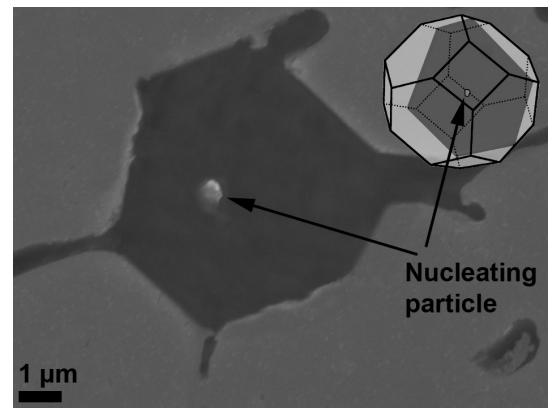

(b)

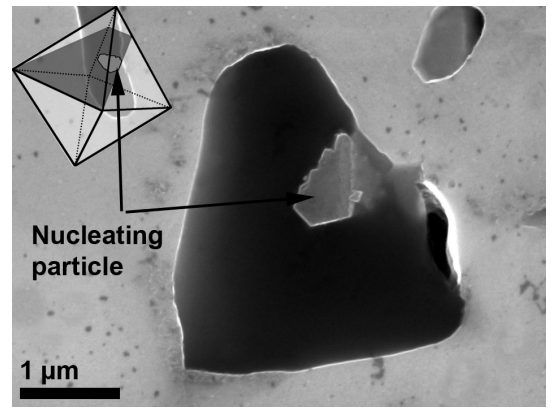

(c)

FiguRe 8. Morphology of primary crystals of $\mathrm{Mg}_{2} \mathrm{Si}$ and their nucleation particles.

\begin{tabular}{|c|c|c|c|c|c|c|c|c|c|}
\hline \multirow[t]{2}{*}{ Crystals } & \multicolumn{8}{|c|}{ Elements, at.\% } & \multirow{2}{*}{$\begin{array}{c}\text { Stoichiometric composition } \\
\text { of the nucleus }\end{array}$} \\
\hline & $\mathrm{O}$ & $\mathrm{Mg}$ & $\mathrm{Al}$ & $\mathrm{Si}$ & $\mathrm{Ti}$ & $\mathrm{V}$ & Mn & $\mathrm{Zr}$ & \\
\hline No. 1 (Fig. 8q) & 24.72 & 0.86 & 37.33 & 4.10 & 24.11 & 8.24 & 0.36 & 0.27 & $\gamma-(\mathrm{Ti}, \mathrm{V}) \mathrm{Al}(\mathrm{O})$ \\
\hline No. 2 (Fig. $8 \mathrm{p})$ & 42.55 & 19.56 & 18.26 & 19.65 & - & - & 0.10 & - & $\mathrm{Al}_{2} \mathrm{O}_{3}+\mathrm{SiO}_{2}+\mathrm{MgO}$ \\
\hline No. 3 (Fig. 8f) & 20.20 & 2.67 & 19.60 & 3.96 & 36.81 & 15.76 & 0.52 & 0.45 & $\alpha_{2}-(\mathrm{Ti}, \mathrm{V})_{3} \operatorname{Al}(\mathrm{O})$ \\
\hline
\end{tabular}

TABLE 2. Chemical composition of nucleating particles of $\mathrm{Mg}_{2} \mathrm{Si}$ primary crystals.

to the stoichiometry of $\mathrm{Mg}_{2} \mathrm{Si}$. The EDX spectra of the interlamellar spacing showed a high concentration of $\mathrm{Mg}$ and $\mathrm{Si}$.

The $(\mathrm{Al})+\left(\mathrm{Mg}_{2} \mathrm{Si}\right)$ eutectic in the $\mathrm{T}$ series and in the TP series has a lamellar morphology, in which long $\mathrm{Mg}_{2} \mathrm{Si}$ plates alternate with $\alpha$-Al (Fig. 77). During solution treatment at $570-575^{\circ} \mathrm{C}$, the $\mathrm{Mg}_{2} \mathrm{Si}$ lamellas disintegrated rapidly into separate spheres. A model of the spheroidization of eutectic lamellas and fibres in alloys of the Al-Mg-Si system is presented in [10].

Mn-containing phase. Due to poor solubility, iron with silicon and aluminium in Al-Mg-Si alloys constitute forms acicular-shaped intermetallic inclusions that reduce the strength and the ductility of the alloys. To reduce the negative effect of this phase, the investigated alloys are additionally doped by $0.6 \% \mathrm{Mn}$ [11, 12].

As has been shown in other studies, the addition of $0.6 \mathrm{wt} \%$ of $\mathrm{Mn}$ in the alloy with a stoichiometric ratio of $\mathrm{Mg}$ : Si close to $2: 1$ improves its mechanical properties. The tensile strength and the yield strength of the alloy increase on average by $30 \%$ with the addition of manganese.

Multi-step nucleation. Generally, there are two possible mechanisms for influencing the structure formation of alloys. One is the influence of modifiers on the solidification front, i.e., changing the surface energy of the growing crystals. The second is based on heterogeneous nucleation, i.e., the alloying components serve as nucleating particles [13].

Adding titanium into the aluminum alloy is an example of the second of these mechanisms. Increasing the number of nucleating particles increases the amount of crystals. This improves the microstructure and the properties of the alloys [13].

In alloys of the $\mathrm{Al}-\mathrm{Mg}_{2} \mathrm{Si}$ intermetallic compounds, which are based on titanium and aluminum (e.g., $\mathrm{Al}_{3} \mathrm{Ti}$ and $\mathrm{Al}_{2} \mathrm{Ti}$ ) can act as a substrate for the nucleation of $\alpha$-Al grains and primary crystals $\mathrm{Mg}_{2} \mathrm{Si}$. Theoretically, the growth of an $\mathrm{Mg}_{2} \mathrm{Si}$ crystal follows a typical faceted growth pattern in convention al solidification conditions. Studies [14, 15] have shown a series of geometric morphologies of primary $\mathrm{Mg}_{2} \mathrm{Si}$, e.g., octahedrons, truncated octahedrons, cubes (Fig. 8). Among these morphologies, octahedrons and cubes with a crystallographic orientation of the facets $\{111\}$ or $\{100\}$ are of great value, due to their high potential as substrates for eutectic growth and their improving effect on the mechanical properties of materials [14, 15.

Figure 8 presents various morphologies of crystals and their nucleating particles. The nuclei were identified according to [16] (Tab. 2).

The $\alpha$-Al matrix has an equiaxed grain structure, with long primary arms (Fig. 9a). When the amount of titanium is increased (above the peritectic values), the number and the size of the nucleating particles increases substantially (Fig. 9p). This, in turn, contributes to grain refinement of $\alpha$-Al (Figs. 5 and 9 ). The results of EDX-analysis showed that the titaniumcontaining nucleating particles were the $\mathrm{Al}_{3}$ Ti phase.

A similar effect of grain refinement when $\mathrm{Ti}$ was added was obtained [17] with HPDC of alloy $\mathrm{Al}_{5} \mathrm{Mg}_{1.5} \mathrm{Si}_{0.6} \mathrm{Mn}$.

Mechanical properties. The results of hardness and tensile tests are summarized in Fig. 10 The result of solution treatment is a significant decrease in both 


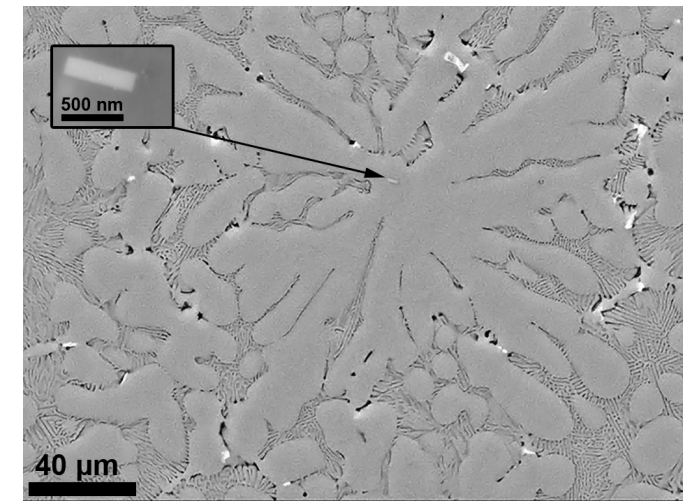

(a)

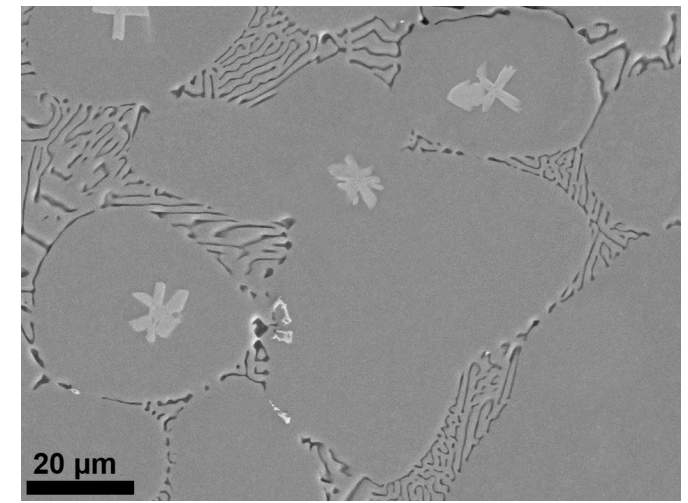

(b)

Figure 9. Grain size and nucleation of $\alpha$-Al dendrites.

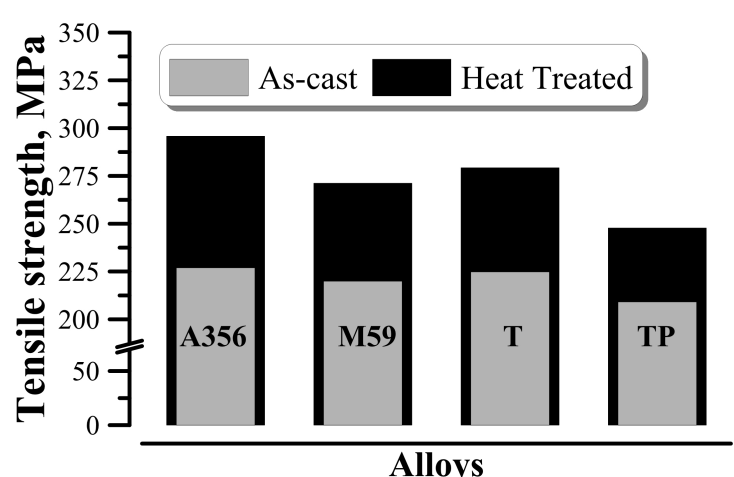

(a)

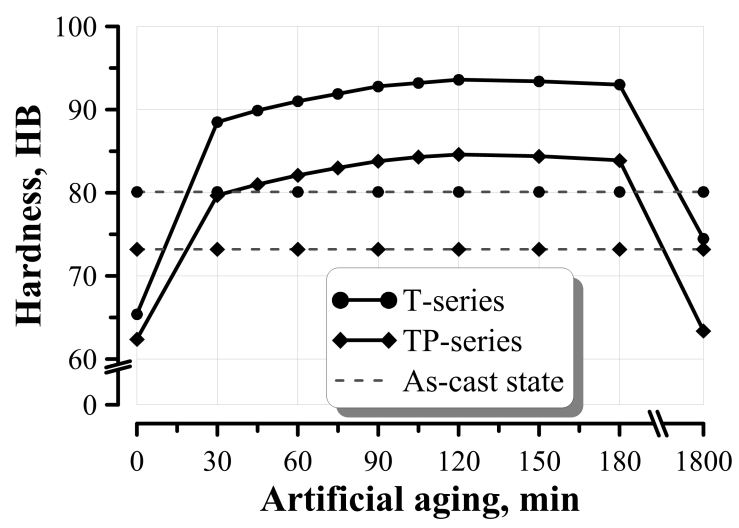

(c)

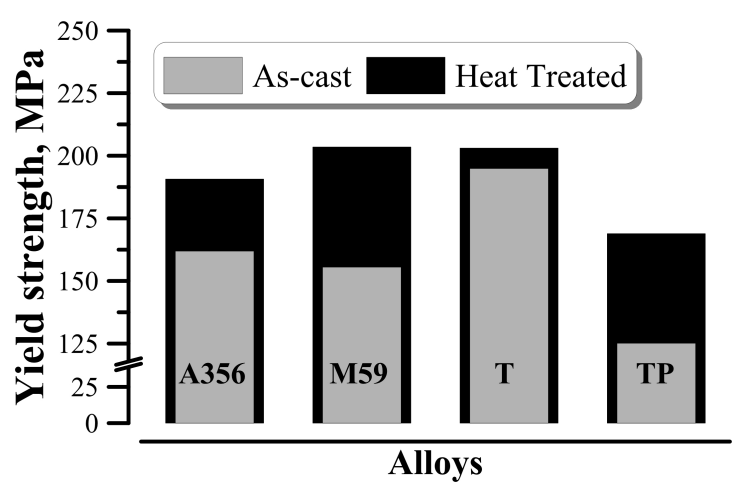

(b)

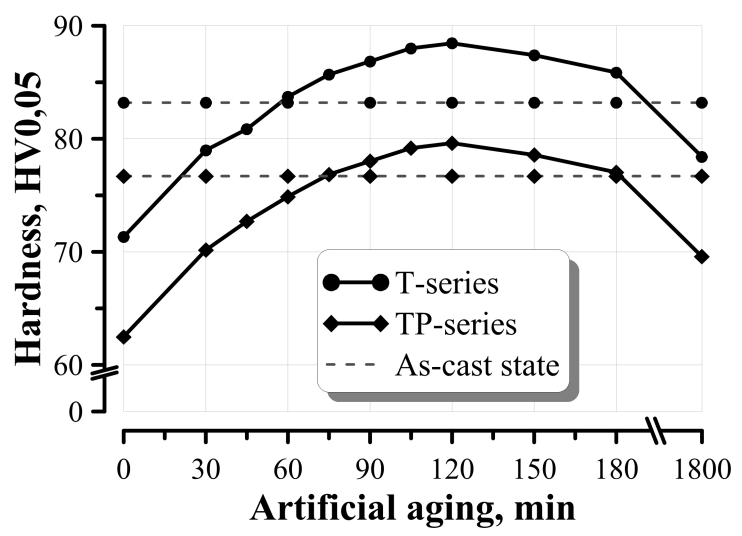

(d)

FIGURE 10. Mechanical properties: (a) tensile strength; (b) yield strength; (c) macrohardness; (d) microhardness.

HB and HV0.05 values. In addition, artificial ageing increases all the mechanical properties of the alloys. The changes during heat treatment are the result of several processes that occur simultaneously during heating. The first process is eutectic spheroidization (Fig. 7). This process reduces the hardness of the alloys [10]. The remaining processes occur in the solid solution, and consist in forming nanoscale precipitates via decomposition of a supersaturated solid solution (SSSS) during ageing. (Fig. 11] [18]. The grains in the solid solution contain plate-like particles, see Fig. 117. One of their sides is connected with curved lines, which can be identified as dislocations.
An investigation of the alloys after homogenization shows the formation of $\beta-\left(\mathrm{Al}_{5}(\mathrm{MnFe}) \mathrm{Si}\right)$ particles. Their lack of coherence with the matrix probably leads to a reduction in the hardness of the alloys (along with decomposition of eutectic lamellas). In addition, the $\beta^{\prime}-\mathrm{Mg}_{2}$ Si particles dissolve during homogenization. However, artificial ageing at $175^{\circ} \mathrm{C}$ causes them to form again (Fig. 11,

It can be expected that the hardness of the tested alloys will initially grow, and then decrease, due to the growth of $\beta^{\prime}-\mathrm{Mg}_{2} \mathrm{Si}$ and their loss of coherency with the matrix.

After 30 min of artificial ageing, an increase in HB and HV0.05 were detected for all alloys that were 


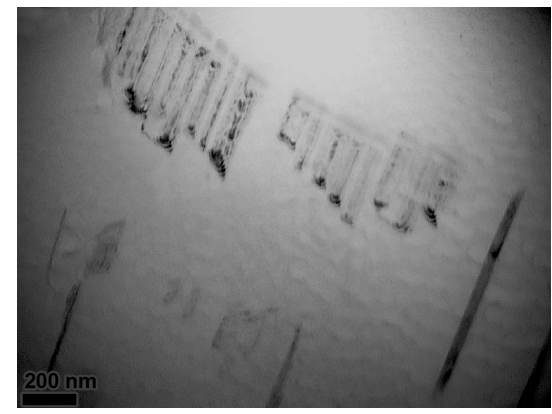

(a)

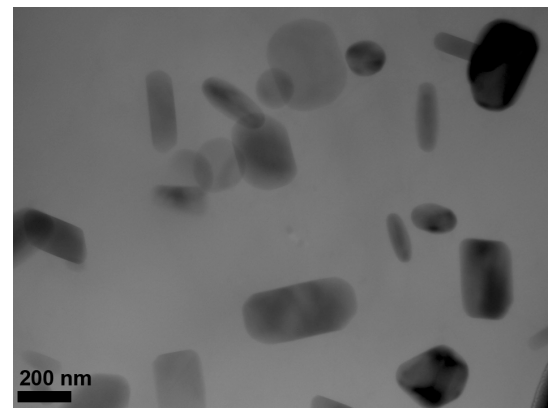

(b)

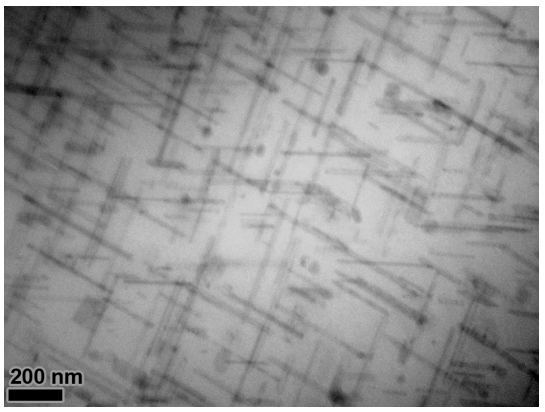

(c)

FIgURE 11. TEM bright field images of precipitates in $\mathrm{Al}_{5} \mathrm{Mg}_{2} \mathrm{SiMn}$ casting alloys: (a) as-cast state; (b) after homogenization; (c) after artificial ageing.

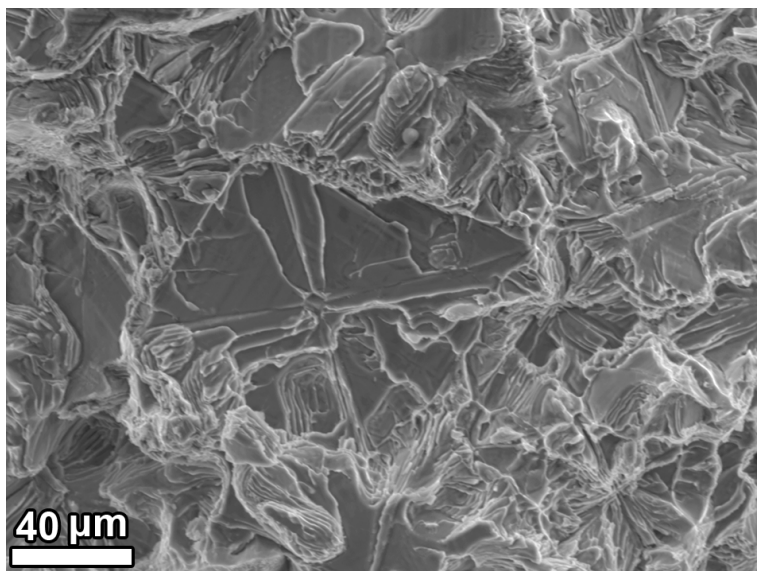

(a)

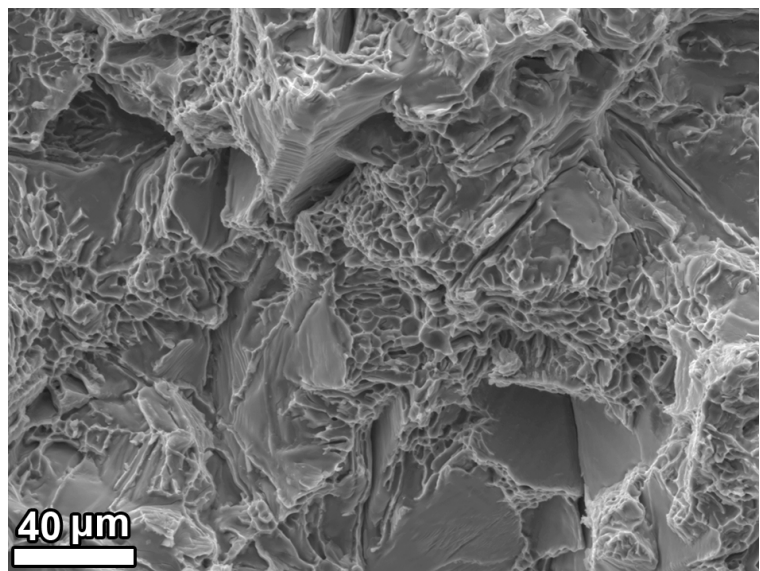

(b)

Figure 12. Fractography of Al-5Mg-2Si-0.6Mn: (a) as cast; (b) after heat treatment.

investigated. In the interval 105-120 min of ageing time, the hardness of both alloys reached maximum values. A prolonged ageing procedure reduces the hardness values for the alloys.

It is shown in [20] that the hardness of hypereutectic $\mathrm{Al}-\mathrm{Mg}_{2} \mathrm{Si}$ alloys is improved with increasing amounts of titanium. It is also reported in 20 that an increasing concentration of titanium (up to $0.4 \mathrm{wt} \%$ ) insignificantly improves the yield strength and the tensile strength of HPDC $\mathrm{Al}_{5} \mathrm{Mg}_{1.5} \mathrm{Si}_{0.6} \mathrm{Mn}$. However, in our alloys (casting in a permanent mould), as shown in Fig. 10 the mechanical properties are slightly reduced (from T-alloy with 0.1 wt\% Ti, to M59 with $0.2 \mathrm{wt} \% \mathrm{Ti}$ and to TP-alloy with $0.26 \mathrm{wt} \% \mathrm{Ti}$ ). In was established in [17, 20, that the addition of titanium has a significant effect on grain refinement, and also on the size of the primary crystals of $\mathrm{Mg}_{2} \mathrm{Si}$. However, there is no information in [17, 20 about $\mathrm{Al}_{3} \mathrm{Ti}$ inclusions, which form after the peritectic point. We observed this phase in TP-alloy (with a Ti content of $\sim 0.26 \mathrm{wt} \%$, which is above the peritectic point). These inclusions may reduce the mechanical properties.

The tensile strength of $\mathrm{Al}_{5} \mathrm{Mg}_{2} \mathrm{SiMn}$ alloys (with the addition of titanium) can reach $300 \mathrm{MPa}$ and elongation of $18 \%$ at HPDC 17]. As is shown in Fig. 10 the yield strength of alloys with a titanium content of $0.1 \mathrm{wt} \%$ can reach $200 \mathrm{MPa}$ in the as-cast state, while the maximum mechanical properties of A356 were achieved only after heat treatment [21.

Fractographic analysis. Both systems of alloys (Al-Si and Al-Mg-Si) have typical characteristics of a transgranular fracture [21, 22].

The behavior of the fracture surface also confirms that the main strengthening phase in the system is the $\mathrm{Al}-\mathrm{Mg}_{2} \mathrm{Si}$ eutectic. Cracks are initiated on the line of the eutectic cells - $\alpha$-matrix grains and eutectic cells - eutectic cells. Additional stress concentrations are caused by the presence of $\mathrm{Al}_{3} \mathrm{Ti}$ inclusions. This confirms our assumption that the deterioration of the mechanical properties in the as-cast state is caused by particles containing titanium $\left(\mathrm{Al}_{3} \mathrm{Ti}\right)$.

The dendrites of the $\alpha$-matrix behave in a similar manner to grains [21, and a strong interaction between inclusions and slip bands generates at the grain boundaries during the plastic deformation process. The final fracture paths tend to pass through the eutectic cells, and a fracture of the eutectic generates the formation of flat areas (Fig. 6). The existence of shrinkage defects leads to a reduction in mechanical properties [21.

Solution treatment leads to fewer brittle surfaces than for the cast condition, and to the formation of a 
ductile fracture. This is associated with spheroidization of the eutectic lamellas. This confirms the reduction in mechanical properties, as shown in the graphs of hardness. The authors observed a similar effect of heat treatment on the formation of the fracture surface 22 .

\section{Conclusions}

(1.) In the as-cast state, the microstructure of the Al-Mg-Si-Mn alloy consists of the following phases: $\alpha$-Al solid solution grains, $(\mathrm{Al})+\left(\mathrm{Mg}_{2} \mathrm{Si}\right)$ eutectic with $\mathrm{Mg}_{2} \mathrm{Si}$ primary crystals in the centre, and also several types of Mn-containing phases.

(2.) Increasing the $\mathrm{Ti}$ content up to $0.2-0.26 \mathrm{wt} \%$ leads to the formation of an $\mathrm{Al}_{3} \mathrm{Ti}$ phase.

(3.) Intermetallic compounds based on titanium and aluminum can act as a substrate for the nucleation of $\alpha$-Al grains and primary $\mathrm{Mg}_{2} \mathrm{Si}$ crystals.

(4.) A higher solution treatment temperature leads to faster eutectic lamella decomposition into smaller segments, and to a spheroidizing effect. Homogenization equalizes the distribution of all elements in the grain.

(5.) Artificial ageing at $175^{\circ} \mathrm{C}$ leads to the formation of strengthening particles, and this leads to an increase in the hardness and the microhardness of the $\alpha$-matrix.

(6.) The main strengthening phase in the system studied here is the $\mathrm{Al}-\mathrm{Mg}_{2} \mathrm{Si}$ eutectic.

\section{ACKNOWLEDGEMENTS}

The authors gratefully thank the Visegrad Fund for support provided for the research presented here. The authors would also like to thank doc. Ing. Jiří Cejp, CSc. and doc. Ing. Jiří Janovec, CSc. for their help with the tensile tests and fractography, and Ing. Jakub Hornik, Ph.D. for supervising these investigations. O. Trudonoshyn would like to thank O. Prach for fruitful discussions. This work was supported by the Ministry of Education, Youth and Sport of the Czech Republic, under program NPU1, project No LO1207.

\section{REFERENCES}

[1] Eigenfeld, K., Franke, A., Klan, S., Koch, H., Lenzcowski, B., Pflege, B. New developments in heat resistant aluminum casting materials, Casting plant and Technology International, Vol. 4, 2004, p. 4-9.

[2] Petkov, T., Kunstner, D., Pabel, T., Kneibl, C., Schumacher, P. Optimizing the Heat Treatment of a ductile AlMgSi- alloy, Giesserei-Rundschau, Vol. 59, 2012, p. 194-200.

http://www.voeg.at/upload/editor/File/archiv/ 2012/7-8/Giesserei_7_8_2012_Artikel(01).pdf

[3] Wuth, M., Koch, H., Franke, A. J. Production of steering wheel frames with an AlMg5Si2Mn alloy, Casting Plant and Technology International, Vol.16, No. 1, 2000, p. 12-24.
[4] Pirš, J., Zalar, A. Investigations of the distribution of elements in phases present in G-AlMg5Si cast alloy with EDX/WDX spectrometers and AES, Microchimica Acta, Vol. 101, No.1-6, 1990, p. 295-304.

[5] L.F. Mondolfo, Aluminium Alloys: Structure and Properties. Butterworth \& Co Publishers Ltd; 2ndRevised edition, December 1979, 971

[6] V. Boyko, O.I. Trudonoshyn, K.V. Mykhalenkov, Melting behavior and heat treatment of Al-Mg-Si-Mn casting alloy alloyed with $0,1 \mathrm{wt} . \% \mathrm{Ti}$ and $0,1 \mathrm{wt} . \% \mathrm{Zr}$, Casting Processes №3, Kiev, Ukraine, 2014, p. 27-37 http:

//ptima.kiev.ua/index.php?option=com_content\& task=view\&id=303\&Itemid=56\&lang=ru\#link4

[7] Boyko V., Link T., Korzhova N., Mykhalenkov K., Microstructure characterization of AlMg5Si2Mn casting alloy, in: Materials Science and Technology (MS\&T) 2013, October 27-31, Montreal, Quebec, Canada, 2013, 1331-1338

[8] Zajac,S , Bengtsson, B, Jonsson, C.2002. Influence of cooling after homogenization and reheating to extrusion on extrudability and final properties of AA6063 and AA6082 alloys. Materials Science Forum pp.396-402 and pp.675-680. DOI:10.4028/www.scientific.net/MSF.396-402.399

[9] F. Vermolen, K. Vuik, S. Zwaag, A mathematical model for the dissolution kinetics of $\mathrm{Mg} 2 \mathrm{Si}$-phases in $\mathrm{Al}-\mathrm{Mg}-\mathrm{Si}$ alloys during homogenisation under industrial conditions, Materials Science and Engineering A254 (1998) 13-32. DOI:10.1016/S0921-5093(98)00763-1

[10] Trudonoshyn O., Prach O., Boyko V., Mykhalenkov K., Selection And Optimization Of Heat Treatment Process To Improve The Mechanical Properties Of Casting Alloys Of The Al-Mg-Si System, Casting Processes Kyiv 2013. № 4 (106), p. 12-21 http: //ptima.kiev.ua/index.php?option=com_content\& task=view\&id=304\&Itemid=56\&lang=ru\#link3

[11] Zhao Zhihao, Meng Yi, Cui Jianzhong, Effect of Mn on microstructures and mechanical properties of Al-Mg-Si-Cu-Cr-V alloy, China Foundry Vol.9 No.4, 2012, p.349-355 http://www. foundryworld.com/ english/foundry/list_show . asp?ID=7727\&MID=377

[12] Chakkrist Phongphisutthinan, Hiroyasu Tezuka, Tatsuo Sato, Semi-Solid Microstructure Control of Wrought Al-Mg-Si Based Alloys with Fe and Mn Additions in Deformation-Semi-Solid-Forming Process, Materials Transactions, Vol. 52, No. 5 (2011) pp. 834 to 841 DOI:10.2320/matertrans.L-MZ201119

[13] Trudonoshyn O., Mykhalenkov K., Morphology and properties of the primary Mg2Si crystals in the Al-Mg-Si alloys, Casting Processes Kyiv 2014. № 5 (107), p. 12-21

[14] C. Li, Y.Y. Wu, H. Li, X.F. Liu Morphological evolution and growth mechanism of primary $\mathrm{Mg} 2 \mathrm{Si}$ phasein Al-Mg2Si alloys // Acta Materialia vol. 59, 2011,pp. 1058-1067 DOI:10.1016/j.actamat.2010.10.036

[15] L. Chen, H.Y. Wang, Y.J. Li, M. Zha, Q.C. Jiang Morphology and size control of octahedral andcubic primary $\mathrm{Mg} 2 \mathrm{Si}$ in an $\mathrm{Mg}-\mathrm{Si}$ system byregulating $\mathrm{Sr}$ contents // CrystEngComm vol. 16, 2014, pp. 448-454. DOI:10.1039/C3CE41646A 
[16] V. Shemet, P. Karduck, H. Hoven, B. Grushko, W. Fischerd, W. J. Quadakkers Synthesis of the cubic Z-phase in the Ti-Al-O system by a powder metallurgical method // Intermetallics vol. 5, 1997, pp. 271-280. DOI:10.1016/S0966-9795(96)00091-X

[17] Shouxun Ji, Douglas Watson, Yun Wang, Mark White, Zhongyun Fan, Effect of Ti Addition on Mechanical Properties of High Pressure Die Cast Al-Mg-Si Alloys // Materials Science Forum Vol. 765 (2013) pp 23-27. DOI:10.1016/j.msea.2012.11.095

[18] C. Ravi, C. Wolverton, First-principles study of crystal structure and stability of $\mathrm{Al}-\mathrm{Mg}-\mathrm{Si}-(\mathrm{Cu})$ precipitates, Acta Materialia 52 (2004) 4213-4227 DOI:10.1016/j.actamat.2004.05.037

[19] Boyko V.,Prach O., Trudonoshyn O., Mykhalenkov K., Microstructure And Natural Hardening Of AlMg5Si2MnCasting Alloy, Bulletin of NTUU "KPI", 2014, p. $47-54$

http://bulletin.kpi.ua/files/2014-1-7.pdf
[20] Yavuz Sun, The Effect of Ti Addition and Aging on Wear Behaviorof AlMgSi Alloys Reinforced with In Situ Al3Ti Particles // Journal of Materials Engineering and Performance, Volume 22(1) 2013, pp 162-169. DOI:10.1007/s11665-012-0217-0

[21] Jiang Wen-Ming, Fan Zi-Tian, Liu De-Jun, Microstructure, tensile properties and fractography of A356 alloy under as-cast and T6 obtained with expendable pattern shell casting process Trans. Nonferrous Met. Soc. China 22(2012) s7-s13 DOI:10.1016/S1003-6326(12)61676-8

[22] G. Mrówka-Nowotnik Influence of chemical composition variation and heat treatment on microstructure and mechanical properties of $6 \mathrm{xxx}$ alloys Archives of Materials Science and Engineering Volume 46 Issue 2 December 2010 Pages 98-107 http://www.archivesmse.org/vol46_2/4623.pdf 